https://helda.helsinki.fi

\title{
Scandinavian perspectives on plant gene technology: applications, policies and progress
}

\section{Eriksson, Dennis}

2018-02

Eriksson, D , Brinch-Pedersen , H , Chawade , A , Holme , I B , Hvoslef-Eide , T A K, Ritala , A , Teeri , T H \& Thorstensen , T 2018 , ' Scandinavian perspectives on plant gene technology: applications, policies and progress ' , Physiologia Plantarum , vol. 162 , no. 2 , pp. 219-238 . https://doi.org/10.1111/ppl.12661

http://hdl.handle.net/10138/233560

https://doi.org/10.1111/ppl.12661

cc_by

publishedVersion

Downloaded from Helda, University of Helsinki institutional repository.

This is an electronic reprint of the original article.

This reprint may differ from the original in pagination and typographic detail.

Please cite the original version. 


\title{
Scandinavian perspectives on plant gene technology: applications, policies and progress
}

\author{
Dennis Eriksson ${ }^{a,{ }^{*}}$, Henrik Brinch-Pedersen ${ }^{a, \dagger}$, Aakash Chawade $^{a, \dagger}$, Inger B. Holme ${ }^{b, \dagger}$, \\ Trine A.K. Hvoslef-Eide ${ }^{c, \dagger}$, Anneli Ritalad ${ }^{d, \dagger}$, Teemu H. Teeri, ${ }^{\mathrm{e},}$ and Tage Thorstensen ${ }^{\mathrm{f}, \dagger}$ \\ aDepartment of Plant Breeding, Swedish University of Agricultural Sciences, P.O. Box 101, 23053 Alnarp, Sweden \\ bDepartment of Molecular Biology and Genetics, Research Centre Flakkebjerg, Aarhus University, 4300 Slagelse, Denmark \\ 'Department of Plant Sciences, Norwegian University of Life Sciences, P.O. Box 5003, NO-1432 Ås, Norway \\ dVTT Technical Research Centre of Finland Ltd., P.O.Box 1000, Fl-02044 Espoo, Finland \\ eDepartment of Agricultural Sciences, Viikki Plant Science Centre, University of Helsinki, P.O. Box 27, 00014, Finland \\ fDepartment of Biotechnology and Molecular Genetics, Norwegian Institute of Bioeconomy Research, P.O. Box 115 NO-1431, Ås, Norway
}

\section{Correspondence \\ *Corresponding author, \\ e-mail: dennis.eriksson@slu.se}

Received 1 June 2017;

revised 10 October 2017

doi:10.1111/ppl.12661

\begin{abstract}
Plant research and breeding has a long and successful history in the Scandinavian countries, Denmark, Finland, Norway and Sweden. Researchers in the region have been early in adopting plant gene technologies as they developed. This review gives a background, as well as discuss the current and future progress of plant gene technology in these four countries. Country-specific details of the regulation of genetically modified plants are described, as well as similarities and differences in the approach to regulation of novel genome-editing techniques. Also, the development of a sustainable bioeconomy may encompass the application of plant gene technology and we discuss whether or not this is reflected in current associated national strategies. In addition, country-specific information about the opinion of the public and other stakeholders on plant gene technology is presented, together with a country-wise political comparison and a discussion of the potential reciprocal influence between public opinion and the political process of policy development. The Scandinavian region is unique in several aspects, such as climate and certain agriculturally related regulations, and at the same time the region is vulnerable to changes in plant breeding investments due to the relatively small market sizes. It is therefore important to discuss the role and regulation of innovative solutions in Scandinavian plant research and breeding.
\end{abstract}

\section{Introduction}

Since the development of recombinant nucleic acid technology and genetic transformation technology in the 1970 s, resulting in the first genetically modified (GM) plant in 1983 (Barton et al. 1983, Herrera-Estrella et al. 1983), gene technologies have been widely applied all over the world in plant research and breeding. In 2016, more than 185 million hectares of GM crops were grown in 26 countries across the world. The top five countries

\footnotetext{
Abbreviations - AC, Appeal Committee; CJEU, Court of Justice of the European Union; CRISPR, clustered regularly interspaced short palindromic repeats; EC, European Commission; EEA, European Economic Area; EFSA, European Food Safety Authority; GM, genetically modified; GTA, Gene Technology Act (Norway); GTLK, Board of Gene Technology (Finland); IP, intellectual property; LRF, Federation of Swedish Farmers; NPBT, new plant breeding techniques; ODM, oligonucleotide-directed mutagenesis; PAFF, Standing Committee on Plants, Animals, Food and Feed; PVY, potato virus Y; TALEN, transcription activator-like effector nucleases; ZFN, zinc finger nucleases.
}

†These authors equally contributed to this work. 
include the United States, Brazil, Argentina, Canada and India, with the United States contributing with the largest area of 72.9 million hectares (ISAAA 2016). More recent techniques for targeted genome editing (GE), including clustered regularly interspaced short palindromic repeat (CRISPR)/Cas9 (Lowder et al. 2016, Quetier 2016), transcription activator-like effector nucleases (TALEN) (Pennisi 2012), zinc finger nucleases (ZFN) (Petolino 2015) and oligonucleotide-directed mutagenesis (ODM) (Sauer et al. 2016), are expanding the versatility and efficiency of plant gene technology beyond random recombinant nucleic acid insertions and are providing researchers and breeders with an increasing number of options for trait management. A Web of Science search on 'plant genetic modification' and 'plant genome editing' gives an indication of the global uptake of these techniques in plant research, with a particularly dramatic recent increase of plant GE research (Fig. 1). However, the commercial application of GM techniques in European plant breeding has been rather slow, despite the fact that many European researchers have been at the forefront of the research in this area. Currently, only one GM crop is commercially cultivated in the European Union (EU); an insect-resistant maize (MON810) developed by Monsanto.

Early recognition of the potential of GM and transformation for plant breeding led to discussions on the appropriate governance including risk assessment, and the first legislation on the deliberate release into the environment of GM organisms (GMO) in the EU came in 1990 with the Council Directive 90/220/EEC. This Directive contained a legal definition of GMO and also listed a number of techniques that are considered to lead, respectively not lead, to a GMO. Whereas both the risk assessment and the authorisation decision were from the beginning in the hands of the EU Member States, a series of revisions in the late 1990 s to early 2000 s led to a more centralised procedure in the EU (Fig. 2). The European Food Safety Authority (EFSA) was established to provide an independent and centralised risk assessment, and a much stronger emphasis was put on the precautionary principle in the legislation for cultivation of GM crops (Directive 2001/18/EC, Official Journal of the European Communities 2001) and for food and feed applications (Regulation 1829/2003, Official Journal of the European Communities 2003). Labelling and traceability requirements were also established through Regulation 1830/2003 (Official Journal of the European Union 2003). There is considerable inherent tension in the $\mathrm{GMO}$ governance framework though, and Casacuberta et al. (2017) have listed a number of contentious issues between actors and values in the GMO risk assessment and management, including (1) the balance between the
EU centralised power and Member States, (2) the balance between consistency and the case-by-case approach and (3) the difficulty of dealing with uncertainty in the risk assessment, which is carried out by scientific experts, while at the same time deliver a clear message on the risk to risk managers.

Similar to the EU GMO Directives and Regulations, the regulatory system in Norway, is based upon the OECD Guidelines (1986). The Norwegian Gene Technology Act (GTA) of 1993 (Genteknologiloven) regulates the production and use of GM microorganisms, plants and animals, where the organisms are modified using gene or cell technology. Under the negotiations of the European Economic Area (EEA) Agreement (1995) between the EU and the EFTA countries, Norway became affiliated with the EU GMO authorisation process, but negotiated to maintain three additional requirements in the aims of the GTA. In addition, Norway also regulates GM in food and feed applications through the Food Act (Matloven) of 2003. As in the EU, any GM approved ingredient in food and feed exceeding 0.9\% must be labelled.

With the advent of the highly efficient and versatile GE techniques, a discussion on how these should be regulated has surged in the last few years. A large part of the scientific literature, as well as position statements from EU agencies, Member State national competent authorities and international organisations agree that the GMO definition of Directive 2001/18/EC is not straightforward applicable to these techniques (for reviews, see Sprink et al. 2016, Wolt et al. 2016, Hartung and Schiemann 2014, Lusser and Davies 2013, HLG-SAM 2017, EASAC 2017). However, the European Commission (EC) has so far not provided any legal guidance for these techniques and their derived products, which currently makes the progress of plant research and breeding in the EU unpredictable and complicates long-term planning.

Plant research and breeding has a long and successful history in the Scandinavian countries (for an overview of, e.g. potato breeding in Sweden, Norway and Finland, see Eriksson et al. 2016). Research on plant biotechnology is carried out at many of the region's largest universities and research institutes and a number of internationally recognised plant research centres and networks have been established, including in Sweden: PlantLink (www .plantlink.se), Umeå Plant Science Centre (www.upsc .se) and Linnean Centre for Plant Biology (www.lcpu.se); in Denmark: Copenhagen Plant Science Centre (www .cpsc.ku.dk) and in Norway: the National Network for Plant Biology Research in Norway (www.plantnorway .com). This review provides a timely overview of the applications and the respective national policies and positions for plant gene technology in the Scandinavian 


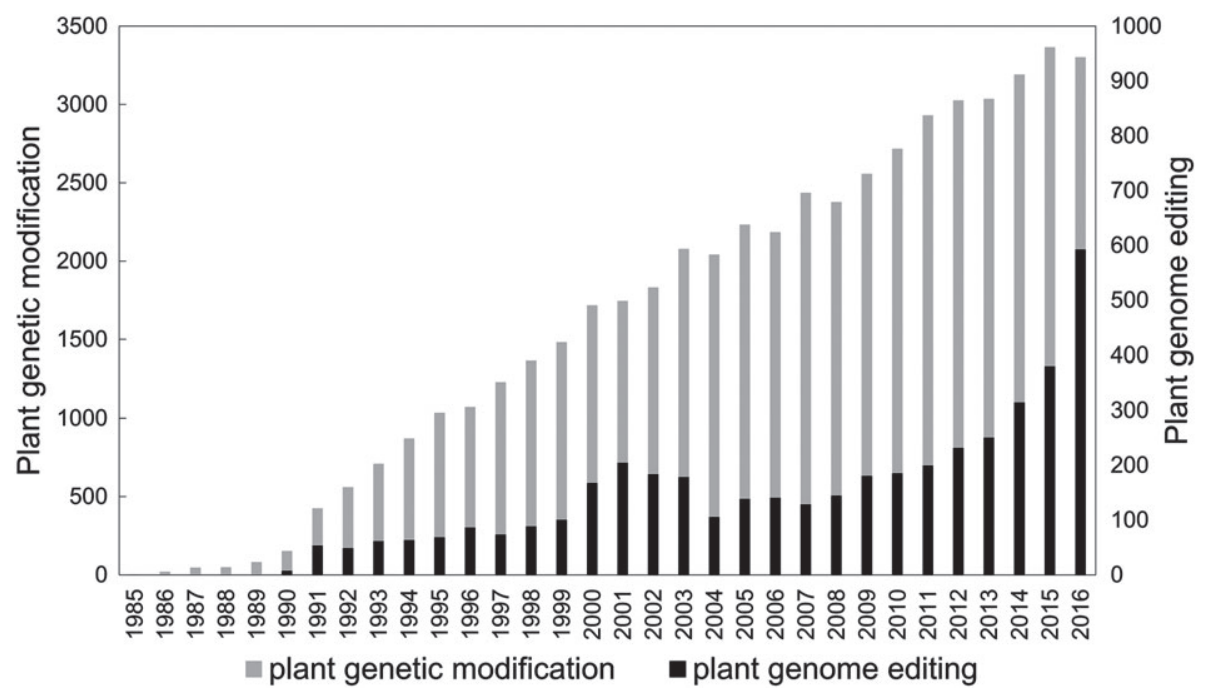

Fig. 1. Web of Science search for plant research using genetic modification (GM) or genome editing, 20/5/17. Search string for GM: (plant OR crop) AND ((genet* AND modifi*) OR transgen*), search string for genome editing: (plant OR crop) AND ((gen* AND edit*) OR (target* AND mutagen*) OR CRISPR* OR TALE* OR ZFN OR meganucleas* OR SDN OR ODM OR (oligo* AND mutagen*)).

region. We will also discuss whether or not national policies on plant gene technology are compatible with other national strategies related to various aspects of sustainable development, as well as do country-wise comparisons against a European background.

\section{Plant gene technology field applications in the Scandinavian countries}

Many plant researchers and breeders in the Scandinavian countries have been early in adopting gene technologies in their work. This has resulted in a large number of experimental GM plant trials both for contained use in greenhouse facilities and field release, and several platforms for the application of plant GE have been established, though there are some differences among the countries. It is beyond the scope of this article to list all contained GM or GE experiments that have been carried out in the region, however, presented below is a comprehensive overview of plant gene technology field research applications to date. There is currently no commercial GM crop cultivation in any of the Scandinavian countries, mainly because the specific crop-trait combination (i.e. maize with Bt-conferred insect resistance) of the only field crop GM event currently authorised for commercial field release in the EU is not of interest to the Scandinavian farmers.

In Denmark the first GM crops, namely glyphosatetolerant sugar beet and fodder beet, were developed in the late 1980s and early 1990s by Maribo Seed, Danisco Seed and DLF-Trifolium A/S. These crops were tested in field trials in several different locations in Denmark between 1990-1999. Additionally, field trials were also conducted with glyphosate-tolerant oilseed rape developed by Aventis (now Bayer A/S) and potatoes with altered carbohydrate composition in the tubers or with resistance to virus (Madsen et al. 2001). A total of 38 notifications for field trials were approved during this period (European Commission 2012b). However, in 2001, the EU placed a 'de facto moratorium' on approvals of GMOs (Library of Congress 2015a). Some Member States, including Denmark, therefore agreed to vote against any new GM approvals until an improved regulation was implemented in EU. This reduced the number of field trial notifications in Denmark to zero in 2000-2004. In the following 8 years (2005-2011) there were a total of $16 \mathrm{GM}$ field trial notifications, some of which were tested in multiple locations (Figs 3 and 4; Table 1A). Two notifications were from the Danish breeding company DLF-Trifolium (glyphosate-tolerant fodder beet, ryegrass with increased leaf fructan) and 2 from the Danish biotechnology company Aresa (thale cress for explosive landmine discovery), while 10 were from Monsanto (glyphosate-tolerant maize NK 603 and sugar beet H7-1) and 2 from Syngenta (glyphosate-tolerant maize GA21). In 2012-2016 there has only been one notification; a $50 \mathrm{~m}^{2}$ field trial with cisgenic barley having increased phytase activity in the mature grain, conducted by Aarhus University in 2012-2013 (Holme et al. 2012). However, since some of the previous notifications were approved for 5 years, there were field trials still going on during 2012 from Monsanto originating 


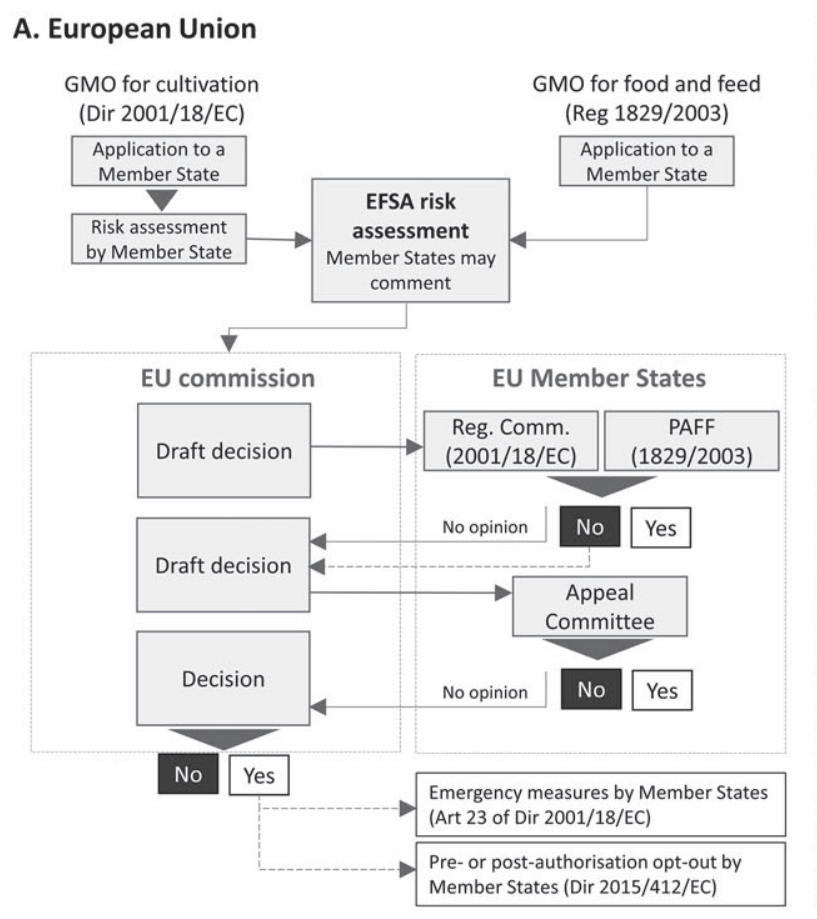

\section{B. Norway}

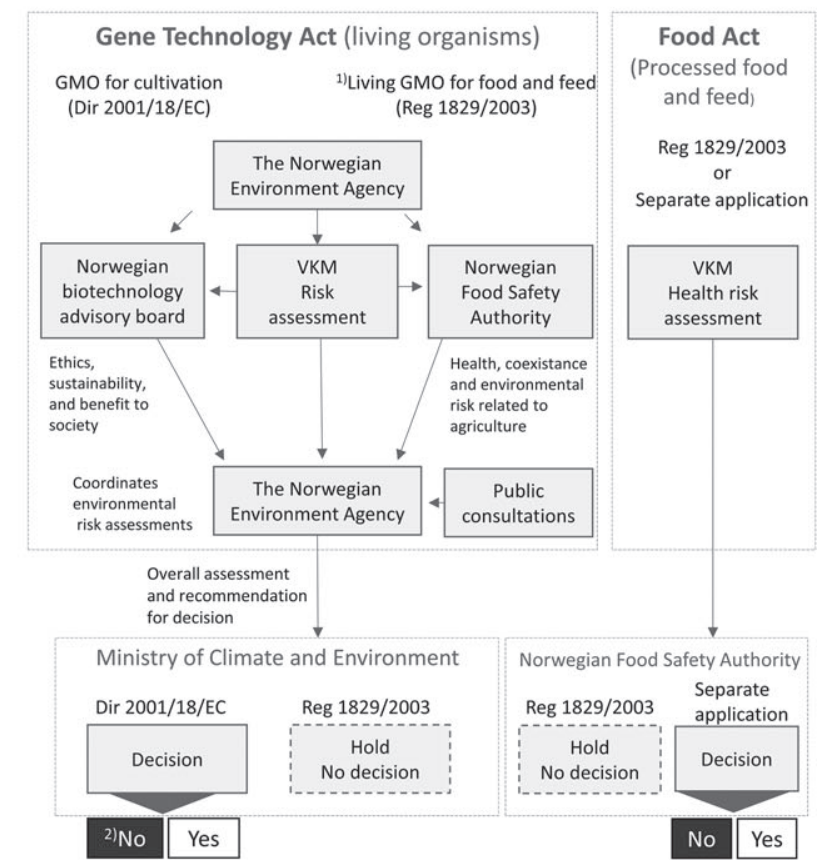

Fig. 2. The GMO authorization procedure in the European Union (A) and Norway (B). (B) The Norwegian evaluation process goes in parallel with EU. The Norwegian Environment Agency distributes the application to the agencies/authorities, which assess the application due to their responsibilities and gives their input to The Norwegian Environment Agency during the EU consultation period. If VKM consider that EFSAs risk assessment (after the consultation period) is not good enough or relevant for Norwegian conditions, VKM perform a new assessment (health and environment) based on EFSAs report, but with focus on conditions relevant for Norway. The other agencies use this report in their final report to The Norwegian Environment Agency. The Ministry of Climate and Environment (MCE) makes their decision after assessment of The Norwegian Environment Agency's recommendations shortly after the EU decision. Applications under the Food Act is coordinated and evaluated by the Norwegian Food Safety Authority. Notes: 1) Reg 1829/2003 is not implemented in the EEA agreement or Norwegian law, so applications under this regulation are not processed according to the new procedures valid for applications under Dir 2001/18/EC shown in the figure. Applications under this regulation are coordinated by the Norwegian Environment Agency (living GMOs) and the Norwegian Food Safety Authority (processed GM food and feed), respectively. The agencies assess the application and give their input to EFSA in the first round in parallel with the process in EU. However, the main assessment takes place after the decision in EU, although decisions are put on hold until the Regulation is implemented in Norwegian law. 2) A GMO that fails to receive authorization in the EU is similarly not authorised in Norway, whereas an EU-approved GMO is authorised in Norway unless the MCE/Government decides to ban it.

from the notifications on maize in 2008 and in 2009 and from the notifications on maize and sugar beet in 2011. However, in 2013 before the growing season, all field trials from Monsanto in Denmark were stopped due to poor experimental results with both maize and sugar beet and because of the resistance against GM plants from the Danish public. There have been no notifications of field trials from 2013 until now and there have been no GM field trials in Denmark since 2014.

In Finland, GM applications for crop improvement started in collaboration with the Kemira Oy company in late 1980s, focusing on potato, birch, gerbera (Elomaa et al. 1993) and petunia (Helariutta et al. 1993). With the aim to start a public discussion on the topic, transgenic potatoes were grown in the Kemira Kotkaniemi research station in 1988 and birch in 1990-1991 (Häggman et al. 1997). A press release was prepared and journalists were invited to the field sites, but the experiments did not attract any interest. In 1992-1993 a 'field trial for commercialization' (in practice the plants were grown on the yards and balconies of the researchers) was done with bright orange petunia lines expressing the gerbera $D F R$ gene. The aim was not to commercialise these plants, e.g. the intellectual property (IP) rights concerning the method and vector parts were not solved, but rather to test the procedure of conducting a field trial as any GMO legislation was not yet in effect. By the appeal of researchers, the National Board of Health had nominated a Recombinant DNA Expert Group who gave statements and issued guidelines about the safety of recombinant DNA technology including field experiments. Later, a similar role was adopted temporarily by the Advisory Board on Biotechnology, and there were efforts to introduce the regulation of GMOs to the law 


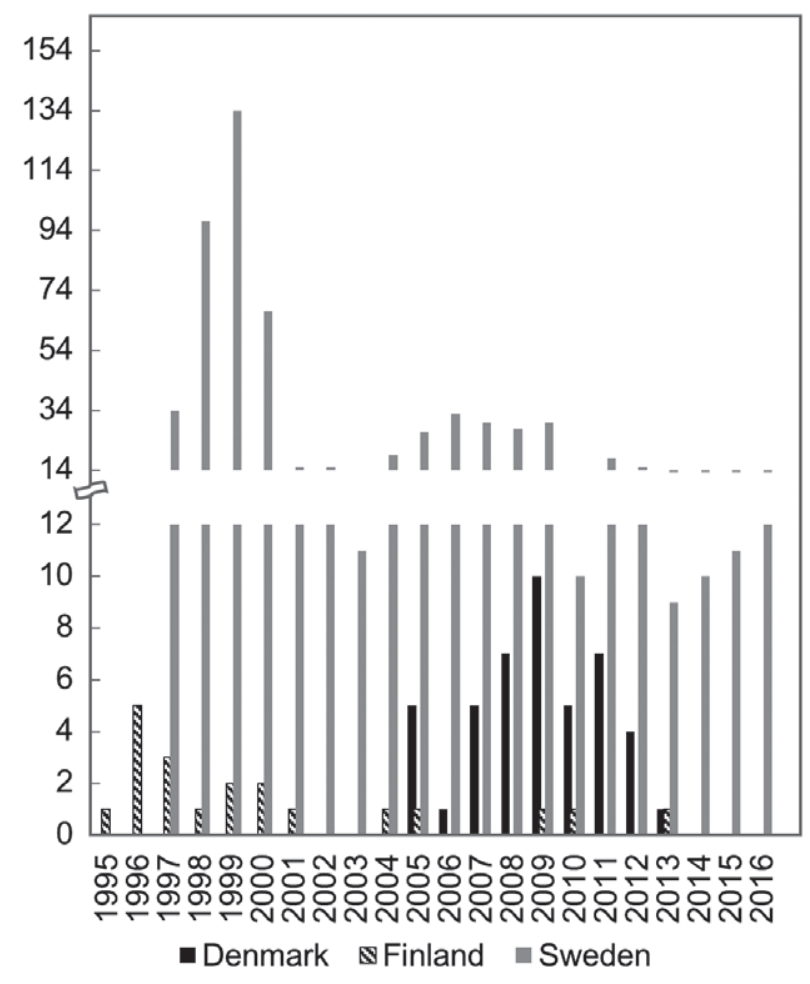

Fig. 3. Number of GMO field trials per year between 1995-2016 in Denmark, Finland and Sweden. Field trials conducted in Denmark in 1990-1999 (38 notifications) are not included as information about the exact areas is not available. For Finland, the actual number of permits, rather than field trials, are presented. Field trials conducted in Sweden in 1995-1996 (four notifications) are not included as information about the exact areas is not available (nor for previous since 1989).

on infectious diseases, however, without success. In practice, the compliance with the guidelines remained voluntary (Matti Sarvas, personal communication). Since 1995, a total of 20 GM plant field trials have been authorised in Finland (Fig. 3) corresponding to a rather modest area of approximately seven hectares (Board for Gene Technology 2017) (Fig. 4, Table 1B). The first trials that were filed under the Gene Technology Act (377/1995) were conducted by The Finnish Forest Research Institute, Punkaharju Research Station with Norway spruce, silver birch and Scots pine in 1996-1998 (Häggman et al. 1997, Aronen et al. 1998, 2003) as well as by Mildola Oy with high-stearic acid oilseed rape in 1995-1998. Transgenic barley and potato were also among the first GM field trials. Boreal Plant Breeding Ltd. carried out the barley experiments in 1996 and 1997 with transgenic material carrying the npt2 marker gene (Ritala et al. 1994) with the aim to evaluate possibilities of pollen-mediated gene flow in a self-pollinated species (Ritala et al. 2002). The GM potato trials, performed by University of Helsinki, dealt with potato virus Y (PVY)

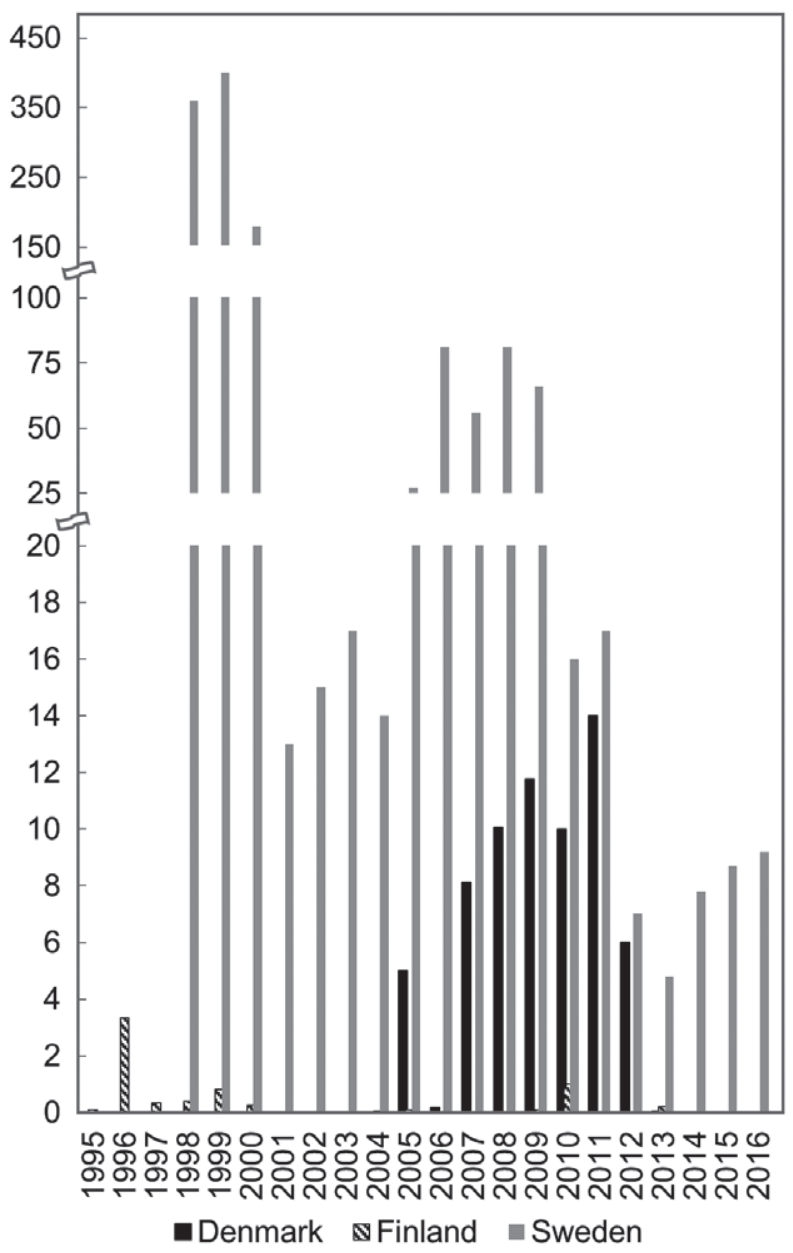

Fig. 4. Total area (hectare) per year of GMO field trials between 1995-2016 in Denmark, Finland and Sweden. Field trials conducted in Denmark in 1990-1999 (38 notifications) are not included as information about the exact areas is not available. Field trials conducted in Sweden in 1995-1997 (nine notifications) are not included as information about the exact areas is not available (nor for previous since 1989).

resistance via sense and antisense orientation of $\mathrm{P} 1$ encoding gene from PVY O-strain (Maki-Valkama et al. 2000, Maki-Valkama et al. 2001). The latest authorization for a field trial was obtained in 2013 for hybrid aspen, with the University of Helsinki evaluating transgenic traits involved in softwood characteristics and growth in 2013-2018. After that no applications have been filed for GM field trials permits.

Norway's first GM field trial was carried out by NTNU in Trondheim with potato containing only marker genes. It took place on the grounds of Kvithamar Research Station in 1991 and lead to a report commissioned from the Norwegian authorities on risk assessment of GM potato in Norway (Rognli and Potter 1991). As mentioned above, the current GTA was in place in Norway in 1993, and the first application of deliberate release 
Table 1. Area (hectare) cultivated with genetically modified (GM) crops in Denmark (A), Finland (B) and Sweden (C), breakdown per crop. Field trials with Arabidopsis thaliana are not presented. (A) Denmark 2005-2013. Field trials from 1990-1999 (38 notifications) are not included as information about the exact areas is not available. No GM cultivation took place 2014-2016. Source: http://gmoinfo.jrc.ec.europa.eu/overview/dk .asp. (B) Finland 1995-2013. No GM cultivation took place 2014-2016. Source: http://geenitekniikanlautakunta.fi/en/deliberate-release/authorisedfield-trials. (C) Sweden 1998-2016. Source: http://www.jordbruksverket.se/amnesomraden/odling/genteknikgmo/faltforsok/genomfordaforsok.4 .300b18bd13d103e79ef80002619.html

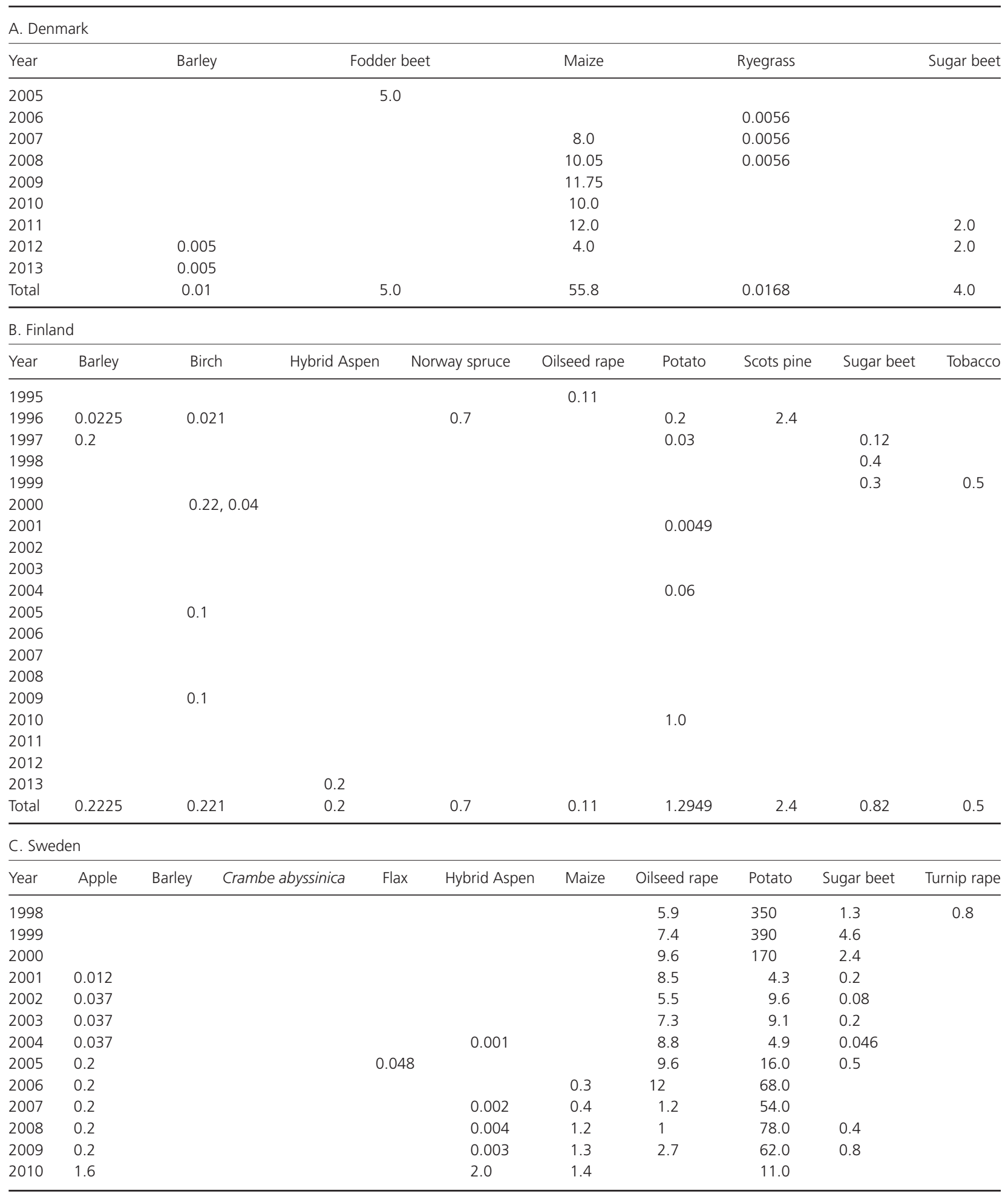


Table 1. Continued

\begin{tabular}{|c|c|c|c|c|c|c|c|c|c|c|}
\hline Year & Apple & Barley & Crambe abyssinica & Flax & Hybrid Aspen & Maize & Oilseed rape & Potato & Sugar beet & Turnip rape \\
\hline 2011 & 1.6 & & & & 3.2 & & & 11.6 & 0.43 & \\
\hline 2012 & 1.6 & 0.073 & 0.2 & & 3.5 & & & 0.35 & 1.26 & \\
\hline 2013 & 1.6 & & 0.1 & & 3.5 & & & 0.01 & & \\
\hline 2014 & 1.6 & & 0.4 & & 5.7 & & & 0.075 & & \\
\hline 2015 & 1.6 & & 0.4 & & 5.7 & & & 1.0 & & \\
\hline 2016 & 1.6 & & 0.5 & & 6.4 & & & 0.7 & & \\
\hline Total & 12323 & 0.073 & 1.6 & 0.048 & 30.01 & 4.6 & 79.5 & 1240.6 & 12216 & 0.8 \\
\hline
\end{tabular}

of a $\mathrm{GMO}$ under this new regulation was an antisense construct of ACC synthase from squash into Christmas begonia to increase the keeping quality (Hvoslef-Eide et al. 1995). This deliberate release permit was given for 5 years in the greenhouses of the Agricultural University of Norway (the present Norwegian University of Life Sciences). According to the European Commission's GMO register (European Commission 2012c), only one application for deliberate field release (field trial) has been notified from Norway in the entire period from 1999-2017. This application from University of Tromsø concerned GM European aspen (European Commission 2012a). There are no commercial breeding companies in Norway that use GM or GE technology in the breeding process. However, the Norwegian breeding company Graminor with research partners (NMBU, NIBIO, UiO, Høyskolen i Hedmark) is using GE technology in research to evaluate gene functions in crops; e.g. potato, raspberry and strawberry. [Correction added on 28 November 2017, after first online publication: The sentence has been updated.] As of today, no food or feed is authorised for sale on the Norwegian market and no GM field crops have been authorised for commercial cultivation, whereas only a number of purple carnations have been authorised for import through the EEA Agreement (Table 2).

Sweden is the only Scandinavian country, which is currently harbouring field trials with GM plants, and in terms of both numbers and total area it has also carried out by far the largest amount (Figs 3,4). GM crops were grown in field trials for the first time in 1989, and the major GM crop under field-testing has been potato, particularly with three consecutive years in 1998-2000 with very large areas (Fig. 4, Table 1C). In the early years (1989-1996), field-testing was carried out with GM oilseed rape, turnip rape, potato and sugar beet. GM field testing has been carried out both by public research institutes such as the Swedish University of Agricultural Sciences (SLU) and Umeå University (UU), private companies such as SweTree Technologies AB (SweTree), Plant Science Sweden, Monsanto, Syngenta, Hilleshög AB, Svalöf Weibull AB, Amylogene and Plant Genetic Systems N.V./Aventis CropScience Nordic A/S, and farmers' associations such as Sveriges Frö- och Oljeväxtodlare. A list of GM trees and crops cultivated in the fields in Sweden in 1998-2016 and the targeted traits are presented below and the available corresponding areas in Table 1C. Transgenic apple (Malus domestica) and

Table 2. GM approvals in Norway to date. EEA, European Economic Area.

\begin{tabular}{|c|c|c|c|}
\hline Event & Applications in the EEA & Modified trait & Approved in the EEA \\
\hline $\begin{array}{l}\text { Carnation } \\
\text { 'Moonlite' } \\
123.2 .38\end{array}$ & Ornamental plant & Changed flower colour & 23/5/07 \\
\hline $\begin{array}{l}\text { Carnation } \\
\text { 'Moonaqua' } \\
123.8 .12\end{array}$ & Ornamental plant & Changed flower colour & 16/3/09 \\
\hline $\begin{array}{l}\text { Carnation } \\
\text { 'Moonvelvet' } \\
\text { IFD-26407-2 }\end{array}$ & Ornamental plant & Changed flower colour & $24 / 4 / 15$ \\
\hline $\begin{array}{l}\text { Carnation } \\
\text { 'Moonberry' } \\
\text { IFD-25958-3 }\end{array}$ & Ornamental plant & Changed flower colour & $24 / 4 / 15$ \\
\hline $\begin{array}{l}\text { Carnation } \\
\text { SHD-27531-4 }\end{array}$ & Ornamental plant & Changed flower colour & $22 / 11 / 16$ \\
\hline
\end{tabular}


pear (Pyrus communis) rootstocks have been field tested to evaluate the rooting ability of the transgenic rootstocks and to evaluate the non-transgenic cultivars of apple or pear grafted onto them for growth, flowering and fruit quality evaluation. Transgenic barley with improved nitrogen efficiency was tested in a small trial in 2012. Transgenic crambe (Crambe abyssinica) has been tested in the fields for improving the overall oil content in the seeds and for evaluating the levels of erucic acid, C22 alcohol and fatty acids or C44 wax esters in the seed oil. Transgenic flax with altered seed oil composition was tested in a small trial in 2005. Transgenic hybrid aspen lines (Populus tremula $x$ Populus tremuloides) have been tested in the fields for (1) wood quality; (2) increased growth in the field; (3) autumn phenology traits and (4) increased wood biomass by increased growth or improved drought tolerance. Transgenic maize with tolerance to the herbicide glyphosate has been tested in the field during five consecutive years (2006-2010). Transgenic oilseed rape has been tested for (1) improved seed oil content and quality; (2) modified storage proteins; (3) male sterility for hybrid production and (4) herbicide (Basta) tolerance. Transgenic potato (Solanum tuberosum) lines have been cultivated in the fields for (1) evaluating resistance to Phytophthora infestans; (2) potato starch with increased levels of amylose; (3) increased amylose content and improved starch biosynthesis; (4) increased starch amylopectin content and (5) increased amylose and oil content. Transgenic sugar beet (Beta vulgaris) was cultivated in the fields for evaluating (1) tolerance to the herbicide glyphosate; (2) resistance to rhizomania and (3) tolerance to glyphosate and resistance to rhizomania. Finally, transgenic turnip rape with tolerance to the herbicide Basta was tested in 1998. In 2017, field-testing is ongoing or planned for the following GM plants: hybrid aspen (UU, SLU, SweTree), Crambe abyssinica (SLU), potato (SLU), Lepidium campestre (SLU), Camelina sativa (SLU), and apple and pear (SLU) (Swedish Board of Agriculture 2017). In 2010 and 2011, commercial production of a GM potato with modified starch quality took place in Sweden following EU authorization; however, this GM event has since been withdrawn from the market.

When comparing the four countries, it is clear that Sweden has carried out most GM plant field trials over the years. We can only speculate about the reasons for this, but it seems as if more companies that have been active in Sweden have been prone to adopt gene technologies in their research and development (R\&D) activities. Swedish universities has also been active in carrying out GM plant field trials, and this may be the reason why Sweden is the only country in Scandinavia which keep carrying out these field trials. Around 2011-2012, there was a general trend in the EU for seed companies to terminate their R\&D activities involving GM technology due to the lack of progress in the authorization process. This is reflected in the decrease in number of notifications for field trials in the EU observed from 2013 to 2017 where there was an average of only 12.6 notification per year whereas the average number were 123 notifications per year from 1991 to 2012. This trend seems to have affected not the least Denmark, over the entire described period Figs 3 and 4 do not give the complete picture for Denmark, as the field trials from 1990 to 1999 are not included because the information about the areas is not available. Finland has had a very modest field trial activity over the years, whereas Norway, which is not included in Figs 3 and 4 due to the almost complete absence of GM plant field trials, has often experienced a relatively strong political opposition to the application of plant gene technologies and this may explain the lack of either private or public field trials.

Given the lack of EU regulatory guidance and the relatively permissive position (for certain applications) taken by some of the Scandinavian countries (see below), it is currently not known whether or not any field trials with GE plants have been carried out in any Scandinavian country. In November 2015, two Swedish research groups received official clearance from the Swedish Board of Agriculture that field release of their CRISPR-modified Arabidopsis lines would not require the permission normally requested for GMO field trials (Swedish Board of Agriculture 2015), and in May 2016 a research group at the University of Turku, Finland, received a similar clearance from the Board of Gene Technology (GTLK) for CRISPR-modified Arabidopsis. However, it is not known whether or not these Arabidopsis lines have been cultivated in the field. Therefore, to date, the only known case of open air cultivation of a GE plant in the region is when a Swedish researcher in 2016 cultivated CRISPR-modified cabbage in a small garden plot, which was publicly announced by serving a meal to a journalist (Cohen 2016). There are also other Swedish research examples of GE crop plants that are in the pipeline for field-testing, given regulatory clearance (Nicolia et al. 2015, Andersson et al. 2017).

\section{Plant gene technology policies in the Scandinavian countries}

The use of GM technology in plant research and breeding in the EU Member States Denmark, Finland and Sweden is regulated through the national implementation of a number of EU Directives as well as direct application of relevant EU Regulations, and also Norway, which is not a EU Member State (only EEA affiliated), 
has regulations based on the EU framework. There are nevertheless differences among the Scandinavian countries, both regarding the details of implementation and the approach to policy developments.

One overall law regulates the use of gene technology in Denmark: Law on environment and gene technology. This law corresponds to the Danish implementation of the EU Directive 2001/18/EC on deliberate release of GMOs and the EU Directive 2009/41/EC on contained use of GM microorganisms. The Law on environment and gene technology is attached with a range of instructions, such as approval on production with GM plants and animals and on relevant fees. In addition, Denmark was the first of the Scandinavian countries to make (1) coexistence rules for GM crops in relation to conventional and organic crops and (2) a law on coexistence that came into force in 2005 (Tolstrup et al. 2003, 2007). The law contains two executive orders, one on cultivation of GM crops (defining isolation distances, cropping intervals, control of volunteer plants, cleaning of machinery and transportation measures) and the other, which is unique to Denmark, on compensation to neighbouring farmers in case of economic loss due to GM admixture. Also, GM farmers and GM handlers need a licence for certain education requirements within the field of coexistence in order to perform the growing, handling and transport of GM crops. Additionally, the law describes the rules for providing information to neighbours and the public about the location of the GM fields. If an unintended spread of GM material to conventional or organic neighbouring fields should happen, the farmers will get compensation. The money will be financed by a fund into which farmers pays 100 DKK per hectare grown with GM crops. The Danish voting behaviour regarding authorization of GM plants is not exclusively following the advices given by EFSA and national experts. After the Directive (EU) 2015/412 on the possibility for EU Member States to restrict or prohibit the cultivation of GMOs in their territory (Council Directive 2015), there are examples where political majorities in the Danish parliament have stopped the approval of GM plants for the Danish market although EFSA and national experts have evaluated that the crops can be grown in Denmark without risk. In a prominent example just after the Directive (EU) 2015/412 was adopted, by a majority overruling the Minister of Environment and Food stopped four GM maize cultivars. Regarding the legal status of new plant breeding techniques, no special adapted policies covering these rapidly developing technologies have so far been developed. Policies are under development and national experts and stakeholders are discussing potential benefits and regulations of these new technologies.
In Finland, the use of GMOs is regulated by Gene Technology Act (377/1995) and the Board of Gene Technology (GTLK) is the competent authority. The Gene Technology Act is based on the EU Directives 2001/18/EC and 2009/41/EC. The Gene Technology Act pertains also to the contained use of GM plants and animals, thus differing from the latter Directive. The Gene Technology Act has been supplemented by Government Decrees. The statutes have been amended several times after the year 1995. The following are the main statutes related to deliberate release of GM plants in force at present: (1) Government Decree on Gene Technology (928/2004), (2) Decree of the Ministry of Social Affairs and Health on the deliberate release of genetically modified organisms (110/2005), (3) Decree of the Ministry of Social Affairs and Health on the differentiated procedure relating to the deliberate release of genetically modified organisms (90/2005), (4) Decree of the Ministry of Social Affairs and Health on Inspection Procedures under the Gene Technology Act (198/2007) and (5) Government Decree on Chargeable Performances under the Gene Technology Act (1158/2009). Regarding GE plants, in November 2013 the US-based company Cibus sent a letter to GTLK to ask if oilseed rape bred with ODM falls under the category of gene technology regulations in Finland. GTLK replied in January 2014 that the use of the ODM-based Rapid Trait Development System (RTDS TM) proprietary technology of Cibus does not fall under the scope of Directive 200I/l8/EC and thus the field evaluations of the aforementioned plants would not be subjected to the notification procedure of the Gene Technology Act (37711995). However, GTLK reminded that if changes in EC regulation take place the Board reserves the right to reconsider their statement (Board for Gene Technology 2017). Similarly in 2016, the University of Turku asked GTLK if CRISPR/Cas9-edited Arabidopsis plants are subject to the gene technology law and statutes in Finland. The interim decision of GTLK on 19 May 2016, valid only for the requested Arabidopsis plants, was that they are not. However, GTLK requested that prior to possible field trials, the University of Turku needs to deliver confirmation with whole-genome sequencing that the plants do not contain any foreign DNA.

In Norway, the development and use of living GMOs (including seeds) is regulated by the GTA (Klima- og miljødepartementet 2015b), while processed food and feed containing GM ingredients is regulated by the Food Act (Fig. 2). Directive 2001/18/EC on deliberate release into the environment of GMOs is incorporated into the EEA Agreement, and thus Norway is affiliated with the EU GMO approval procedures. According to $\$ 10$ of the GTA, GMOs approved in the EU under Directive 2001/18/EC are also authorised in Norway and do not 
need a specific Norwegian approval; however, they can be prohibited if they contravene the criteria of the GTA. In addition to be safe for the environment and human health, GMOs should be in accordance with societal benefits, promote a sustainable development and be ethically justifiable (Hvoslef-Eide 1995, 2012). Norway has been granted these additional requirements under the EEA agreement provided the EU does not suspect that Norway uses this as a hidden trade barrier. Through its EEA agreement, Norway is an observer in the committees of the GMO decision process in $\mathrm{EU}$, but has no voting rights. According to the GTA, an independent (but governmentally appointed) Biotechnology Advisory Board will evaluate and make statements on GMO matters regulated by the law. The board has no approval authority, but gives advice to the Government with specific focus on the societal benefit, sustainability and ethics criteria of the GTA. In general, the majority of the members vote against recommendation of approval of GMO applications. Until recently, there has been an interpretation of the Gene Technology Act that all GMO approvals in any EU Member State under Directive 2001/18/EC that had not yet been evaluated by Norwegian authorities were prohibited. However, in 2014 the Ministry of Climate and Environment declared that nine EU-approved GMOs were authorised in Norway according to the Directive (Klima- og miljødepartementet 2015a), because they had not been actively prohibited according to the law. On 2 June 2017, the Norwegian government prohibited import of four of these GMOs (three oilseed rape events and one maize event), while five cultivars of carnations were approved (Table 2). The maize event 1507 was prohibited because it was considered to not be ethically justifiable as it contains genes for tolerance to glufosinate-ammonium, which is not authorised for use in Norway. Norway has through GTA regulations prohibited another six GMO events approved in the EU under Directive 2001/18/EC (Klima- og miljødepartementet 2000). On 5 July 2017, the Ministry of Climate and Environment established new efficient procedures for the evaluation of GMO applications under Directive 2001/18/EC that replaced an elaborate two-step evaluation process (before and after EU approval). The main part of the Norwegian evaluation will now take part in parallel with the EU evaluation, which secure that Norwegian authorities can take a decision according to the GTA shortly after EU approval, and not after a new round of evaluations as before (Norwegian Ministry of Climate and Environment 2017). Since Norway already, through the EEA agreement and its adaption to the Directive 2001/18/EC, is allowed to restrict or prohibit distribution and growth of GMO on criteria such as societal benefits, sustainable development and ethics in addition to health and environment, the Ministry of Climate and Environment do not see any need to change the law to implement Directive (EU) 2015/412.

In contrast to Directive 2001/18/EC, Regulation (EC) No 1829/2003 (Council Regulation 2003) on GM food and feed is not incorporated into the Norway-EEA agreement. However, Norwegian authorities still evaluate the applications in a two-step process, where the Norwegian Environment Agency is responsible for evaluating living GMOs under the GTA and the Norwegian Food Safety Authority is responsible for evaluating processed food and feed produced from GMO under the Food Act (Fig. 2). Since the two authorities evaluate GMOs under two different acts with different evaluation criteria (only health, coexistence and environment for the Food Act, and in addition ethics, benefit for society and sustainability for the GTA) they can come to different conclusions. However, since the regulation is not included in the EEA agreement, Norway will not give any final decision on any $\mathrm{GMO}$ or processed product from this GMO even after the risk assessment has concluded that it is safe. Norway has decided to process all the applications under Regulation No 1829/2003/EC even though this Regulation is not yet included in the EEA agreement. This entails that there will be a portfolio of EU-approved applications that are processed after Norwegian law ready for the Government to decide once the agreement is in place. Another consequence of the regulation not being part of the EEA Agreement is that living GMOs with expired authorization under Directive 2001/18/EC in EU (and Norway), but with renewed authorization under Regulation No 1829/2003/EC, are not automatically authorised in Norway. To get a formal authorization for marketing processed food and feed produced from GMO in Norway, a separate application under the Food Act (Fig. 2) is required even if the product is already approved in the EU. However, since the market is so small, very few companies do this, and there has been none the last 10-15 years. Living GMOs and processed food and feed products produced from GMOs with functional antibiotic resistance genes that can be identified by analysis are prohibited by the Food Act. The regulation of processed food and feed containing GMO was included in the Food Act in 2005 to harmonise with the EU regulations from 2003. Until then, GM feed did not require any specific approval. As an interim arrangement, GM feed notified by the industry that had been used in Norway until the new regulations, and that already was approved in EU, could be exempted from the approval requirements for 3 years. The interim arrangement ended in 2008, and the Norwegian Seafood Federation has each year applied for exemption from the requirements to apply for approval of GM fish feed from the 
Norwegian Food Safety Authority for 19 GM products (Mattilsynet 2013, 2014). Until 2013 they got an exemption each year, however, in 2014 the application was declined because the industry never took advantage of the possibility to use GM feed.

In Sweden, the EU Directive 2001/18/EC is implemented mainly through the Swedish Environmental Code (1998) as well as by the Regulation 2002:1086 on deliberate release of GMOs to the environment, whereas the Regulation 2000:271 on contained use of GMOs is specific to Sweden (as in Finland) in the sense that only the contained use of GM microorganisms is regulated in the EU whereas Sweden also includes GM plants in this Regulation. EU Regulations, such as No 1829/2003/EC, No 1830/2003/EC and No 1946/2003/EC, are directly applicable in all EU countries including Sweden. Directive (EU) 2015/412 on the possibility for the EU Member States to restrict or prohibit the cultivation of GMOs in their territory has not been implemented in the Swedish legislation; however, a Swedish Government Official Report suggested that the Swedish Environmental Code could potentially be amended to implement this Directive, even though the report could not predict that it would be relevant for any crop or trait in the foreseeable future (SOU 2016:22). Since 1994, the Gene Technology Advisory Board (Gentekniknämnden), with seven experts and one representative from each political party in the Swedish parliament, has been providing non-binding advice to the Swedish Government on the use of gene technology. Regarding the legal status of new plant breeding techniques (NPBT), and particularly GE, the Swedish Government and the Swedish Board of Agriculture have on several occasions officially supported the position that a product needs to contain detectable recombinant nucleic acid sequences in order for it to be defined as a GMO according to the definitions contained within Directives 2001/18/EC and 2009/41/EC. In November 2015, the Board of Agriculture assessed that, according to current legislation, a CRISPR/Cas9-mutated Arabidopsis should not be subject to the GMO regulatory process under the condition that it does not contain foreign DNA (Swedish Board of Agriculture 2015), which was followed by a letter from the Swedish Ministry of Enterprise and Innovation to the EC Directorate General Health and Food Safety (DG-SANTE) emphasising that the legal framework in the EU for GMO is not appropriate for handling some of the new GE techniques (Swedish Ministry of Enterprise and Innovation 2016). A similar stance as in Finland was taken to the request from the company Cibus whether or not field release of an ODM-modified oilseed rape needed permission according to the GMO regulation (Fladung 2016). The Swedish position on GE was reinforced in January 2017 in a written opinion referred to the Court of Justice of the European Union (CJEU) regarding the request from the French High Court to the CJEU to clarify the legal status of GE techniques (Conseil D'État 2016). The Swedish position argued that GE resulting in targeted mutagenesis including less than the technical detection limit of 20 nucleotides should not be considered GMO whereas GE resulting in targeted insertion of more than 20 nucleotides should be considered GMO (Swedish Ministry of Foreign Affairs 2017).

Several countries around the world seem to take more or less the same stand on GE as Sweden has indicated, including in the EU; Finland and the Netherlands (the Netherlands Government 2017) and outside of the EU; Argentina (Whelan and Lema 2015), Canada (Smyth 2017) and the United States (Ledford 2016), where the authorities have decided not to regulate GE in the same way as GM, or do so on a case-by-case basis. Australia and New Zealand have a coordinated regulatory framework and they have come to the opposite conclusion: to regulate GE as they regulate GM (Logan 2017; MacManus 2017). The rest of the world, including the two large agriculture-producing countries Russia and China, as well as the EU, have yet not decided how to deal with the emerging GE technologies.

In an EU context, the occasional positions taken by the governments of Finland and Sweden on plant GE applications are interesting as they to some extent adhere to a product-based interpretation of the EU GMO Directives in the sense that an organism should contain, and not only have been developed by the use of, recombinant nucleic acids in order to be classified as a GMO. We have so far not seen any official position from Denmark, nor from Norway, on this matter; however, it will be very interesting to follow the imminent developments in the EU regarding GE and other new plant breeding techniques (NPBTs) and how the Scandinavian EU Member States position themselves.

Whether a GE plant is considered under the current legislation on GM or not has wide economic implications for small and medium-size breeding companies in Europe and, as a consequence, also for our farmers. The GM regulations place heavy economic burdens on the product, and only the economically strong multinational companies can afford to pay the price of getting a GM variety or a GM-derived product to the market. This is the unintentional effect of strict regulations. Using GE technologies, where no foreign DNA is added, has been considered by several authorities to be similar enough to conventional breeding to not be subject to the same risk assessment as GMOs. If this position is adopted by EU, it will empower small and medium-size breeding companies, such as several in Scandinavia, to afford using 
more precise techniques in their breeding and improve their ability to compete with the large multinational companies.

\section{Implications of plant gene technology policies on other national strategies}

A sound use of plant gene technologies is highly relevant to facilitate achieving the objectives of several national sector strategies in the Scandinavian countries, such as those related to research, food production, environmental goals, bioeconomy, sustainable agriculture etc. This section will analyse whether or not this is reflected in a number of relevant national sector strategies across the region.

The latest position paper concerning Plant Breeding from the Danish Ministry of Environment and Food is named Plants for the Future. In this paper, the Ministry states that efforts must be made to strengthen Danish plant breeding and that public involvement in this regard is necessary. Focused efforts will be able to contribute to adapting agriculture to upcoming climate change and to support the conversion of Denmark into a bio-based society. The Ministry outlines four goals that they want to support, i.e. (1) reduction in pesticide utilisation, (2) breeding of varieties suitable for organic farming, (3) breeding for improved utilisation of nitrogen and phosphorous and (4) development of crops and plant varieties able to be included in future bioeconomy products (Ministeriet for Fødevarer Landbrug og Fiskeri 2014). The details of these efforts are planned in dialogue with the stakeholders of plant breeding in Denmark, i.e. 'Crop Innovation Denmark' (a public-private collaboration between Danish breeders, the Danish Agriculture \& Food Council and Universities) and Organic Denmark (an association of organic companies, organic farmers and organic consumers). Although not mentioned in the position paper, Plants for the Future, the use of plant gene technologies would greatly facilitate the achievement of several of these goals, i.e. reduction of pesticides and increased utilisation of nitrogen and phosphorous. For the breeding of varieties suitable for organic farming it is, however, unlikely that plant gene technologies will be used as organic producers are very reluctant to apply any kind of biotechnology in their breeding programs.

In Finland, the Ministry of Agriculture and Forestry has twice outlined a strategy for gene technology and its implementation, first for the period 2003-2007 and later for 2009-2013 (Finnish Ministry of Agriculture and Forestry 2009). The strategy was made to ensure controlled implementation of gene technology to sustain viability of agriculture, sustainable use of natural resources, and production of safe and high quality goods, overall transparent operations and efficient surveillance. In the strategy it was especially mentioned that we need to have research to support, develop and sustain high quality expertise to be able to implement gene technology in agriculture and forestry. In 2009, the Ministry of Agriculture and Forestry was preparing national coexistence regulations on the basis of the recommendation of 2003/556/EC. A Government bill 246/2009 dealing with especially requirements concerning location, pre-assessment, consent and permits of GM cultivation was discussed in the parliament. However, this was put on hold for several years until being currently opened again in 2017. In 2014, a Finnish bioeconomy strategy was outlined by the Ministries of Economic Affairs and Employment, Agriculture and Forestry and the Environment (Finnish Bioeconomy Strategy 2014). It defined four major goals: (1) a competitive operating environment for bioeconomy, (2) new business from the bioeconomy, (2) a strong bioeconomy competence base and (4) accessibility and sustainability for biomasses. Even though plant breeding or gene technology were not specifically mentioned, it is obvious that for each one of these goals plant biotechnology has lot to offer and plant breeding is at the very core of a Finnish bioeconomy.

In November 2016, the Norwegian Government presented their Bioeconomy Strategy 'Kjente ressurser - uante muligheter' (Norwegian Bioeconomy Strategy 2016). In this strategy the government emphasised the need of a green shift in the Norwegian economy based on sustainable use of renewable biological resources. The bioeconomy will be developed through investments in bio-based industry and innovation, new technology and knowledge. The aim is a sustainable, efficient and profitable production, harvest and use of renewable biological resources. There is a specific focus on the bioeconomy's role in an environmentally friendly low emission economy. Furthermore, the Government wants to increase agricultural food production, through rationalisation and increased research and development on the genetic potential in plants and animals, and through improved breeding. However, plant gene technology is not mentioned in this regard. Biotechnology is central in the Bioeconomy Strategy, but generally for processing biological material for production of high value products and not for changing the genome of crop plants using plant gene technology. Earlier strategies (Stortingsmeldinger) like 'Velkommen til bords' (2011-2012) generally focus on the challenges related to GMO, both ethical, regarding patent rights, traceability, spreading etc., and not on the possibilities this technology provides. The next Stortingsmelding (2016) emphasised the need for plant material adapted to Norwegian climate and the role of the Norwegian 
breeding company Graminor in this regard. Recently, the Standing Committee on Business and Industry made a setting to the Parliament about this 'Stortingsmelding' on the use of GE technology. They recommended to the Norwegian Parliament that the new technology need more research and must be regulated as GMOs under the Gene Technology Act. On 26 April 2017, an unanimous parliament voted in support of the Committee's setting.

In Sweden, the recent National Food Strategy, launched in January 2017, specifically mentioned that novel technical innovations should be utilised in plant breeding activities to contribute to a sustainable production and to the adaptation of agriculture to a changing climate (Swedish Government Official Report 2016/17:104). It also stated explicitly that the biosafety assessment of novel bred cultivars should focus on the traits, regardless of which breeding techniques have been used in the process. We find this highly encouraging and in line with earlier Swedish position statements on GE technology (see above). The Swedish position on novel breeding techniques can also be considered relatively appropriate for the ambitions in the National Research Strategy for 2017 (Swedish Government Official Report 2016/17:50), which emphasised the importance of a circular, bio-based economy of which the food value chain is an integral part. The National Research Strategy also aims to promote Sweden as a testbed and demonstration environment for novel technologies. As most EU countries no longer harbour GMO field trials, it is therefore important that Sweden continues to allow a continuation of research utilising GMO field trials as well as promotes the establishment of field trials with GE plants. The Swedish Government has established 16 national Environmental Objectives (Swedish Environmental Protection Agency), and we believe gene technologies may facilitate the work to achieve several of these goals. To give a few examples, agriculture is crucial for reduced climate impact, as efficient breeding for a highly productive and environmentally sustainable crop management will contribute to climate change mitigation. A non-toxic environment may also, in part, be achieved through the use of gene technologies as these greatly facilitate the development of sustainable crop protection while reducing the dependence on pesticides. In this context, we find it peculiar that Sweden recently voted no to the authorisation in the EU of two GM maize events (see above), while referring to this particular national Environmental Objective as basis for that decision, given that these GM maize events are considered safe by EFSA and would contribute to a reduced dependence on insecticides in maize cultivation. Also zero eutrophication (through breeding for increased nutrient use efficiency), a varied agricultural landscape (through breeding to maintain culturally valuable landraces) and a rich diversity of plant and animal life (through breeding for reduced dependency on pesticides, and breeding for highly productive agriculture that allows habitat preservation) are Environmental Objectives that also may be served by gene technologies.

There are both similarities and differences in the way the potential benefits and contributions to the society of plant gene technologies are perceived in the Scandinavian countries. Norway indeed puts a lot of emphasis on sustainable development and use of renewable resources, however, not more clearly acknowledging that plant gene technologies may contribute to these goals is from our perspective worrying. Also, the recent vote on the authorisation of two GM maize events in the EU shows that it is important to maintain a continuous discussion with policy makers on these matters. A recent announcement on September 13 from the Swedish Government to make a large public investment in breeding is highly encouraging though (Swedish Government 2017), particularly in light of the earlier statement in the Swedish National Food Strategy that any risk assessment of novel bred cultivars should focus on the traits.

\section{Stakeholder opinions in the Scandinavian countries}

A reciprocal relationship between policy developments and stakeholder opinions, including in particular the public as a major stakeholder, is often guiding the development of regulations as well as public R\&D priorities. Below is an outline of some of the major trends among the stakeholder opinions in the Scandinavian countries.

A major opinion in Denmark on the use of GMO came in 2016 when the Danish Ethical Council recognised that, based on the many studies conducted on GM crops, there are no indications it should be harmful to eat $\mathrm{GMO}$ or food derived from animals fed with GMO (Råd 2016). The use of GMO seems to be largely driven by its application. The current Danish animal production is dependent on cheap protein feed and two thirds of the protein included in the feed in Danish agriculture is imported from other countries, mainly Argentina, Brazil and the Unites States. Around $60-90 \%$ of the imported soybean is GM (Bosselmann et al. 2015). GM food products are not available in Denmark. However, studies generally conclude that the opinion on gene technology is largely dependent on the application of the GMO. Lassen et al. (2009) gives three parameters that are important for the consumer's evaluation and acceptance of the technologies: (1) use; (2) risk and (3) moral. The protests against GM food can largely be seen 
as a response to the fact that public regulation is focusing on the handling of environmental and health risks and not in sufficient degree is covering the public concerns on applications and moral/ethical considerations (Lassen et al. 2009). In one Danish study it was investigated whether or not cisgenic crops are perceived as more natural and more acceptable than transgenic crops (Mielby et al. 2013). Using focus group interviews, five lines of argument about naturalness with a bearing on the assessment of cisgenic crops as well as GM crops in general were identified. The study concluded that, depending on perceptions of naturalness, some people would agree that cisgenic crops are more acceptable than their transgenic counterparts (Mielby et al. 2013).

In Finland, Kaljonen and Rikkonen (2004) carried out a study of the future of multifunctional agriculture and compared views of farmers and agri-food experts. Their findings were that GMOs are seen as a new emerging risk in the future, that the use of GMOs is expected to increase and that it will have an impact on agricultural practises. However, substantial variation was seen in the opinions within and between the two groups ranging from GMO-free areas to full GMO practises thus bringing additional uncertainty to the development of GMOs and their impact. Both groups believe that agricultural output remains at the same level but radical changes are foreseen and depend in the case of GMOs on how the commercialisation is realised. Related to the Government bill on coexistence (249/2009), several academics signed an appeal in 2011 to emphasise that the proposal puts cultivation of EU-authorised GM varieties in a significantly weaker position compared to traditional or organic farming. In the appeal, it was underlined that if this proposal would become a reality it would place GM crops and cultivation off balance, seriously damaging the technological development, freedom of livelihood and possibilities of biosciences in Finland (Hollo 2016). The Finnish food safety authority EVIRA very clearly announces that GM foods are safe due to the fact that prior to authorization they are subject to a very thorough approval process (Finnish Food Safety Authority 2017). Already in 2010, the advisory board on biotechnology (BTNK) published a leaflet on GM foods to provide information for consumers (Advisory Board on Biotechnology 2017) and very clear knowledge is also available on GM and novel foods at Ministry of Agriculture and Forestry pages (Maaja metsätalousministeriö 2017).

Various stakeholders in Norway are organised in the 'Nettverk for GMO-fri mat og fôr' (Network for GMO-free food and feed), including farmer organisations, environmental organisations and food retailers. Their agenda is to secure the consumers' right to choose GM-free food, feed, seeds and animals and restrictive use of GMO both nationally and internationally. The network commissioned a survey on consumer attitudes on GM food (Bugge and Bartmann 2017). According to the report, only $15 \%$ of Norwegian consumers are positive to GM products in Norwegian shops, while $50 \%$ are negative. However, young people are more positive than older people, and $31 \%$ thought GM food would be necessary to feed the world in the future, while $37 \%$ did not. The survey confirms the results of a previous meta-study finding Norwegian consumers to be among the most sceptical towards GMO (Hess et al. 2013). In Norway there is currently a debate on how the CRISPR technology should be regulated. Many stakeholder organisations (e.g. farmer associations such as Norges Bondelag, Norges Bonde- og Småbrukarlag) and NGOs (e.g. Bellona, Greenpeace) would like the technology to be regulated under the Gene Technology Act, whereas the biotechnology research community are more in favour of the technology being regulated as conventionally bred plants in cases where no new DNA is introduced into the crop genome. However, although the farmer organisations are negative to GMO, their attitude to the new GE technology is currently tentative, but hopeful. In contrast to the farmer organisations in EU, Norwegian farmers reject all use of GM feed. When it comes to genome editing, the breeding companies are taking advantage of the attitude among Norwegian producers and are planning to explore these techniques in future breeding programs, particularly if the authorities conclude not to regulate GE plants as GM, since the costs of approval is tremendous for GM-regulated products.

The Swedish people seem, to some extent, be sceptical to GM products, as was seen in a study conducted by milk farmers where $63 \%$ of the respondents preferred that the milk they consumed was GM-free. On the other hand farmers support the use of the cheaper GM-based fodder (Library of Congress 2015b). However, opinions of people and other stakeholders on GM products based on the surveys conducted by researchers and journalists may not necessarily depict the behavioural situation in the event when GM products are actually available (Lusk et al. 2005). A study was conducted in several countries, including Sweden, to depict the real-market situation where the consumers had the possibility to purchase GM products (Knight et al. 2007). Fruits labelled as organic, conventional or spray-free GM were displayed in road-side stall and the consumers were given the possibility to choose among the three types of fruits. When the prices were equal, spray-free GM fruits achieved a market share of around $20 \%$ but it soared to $43 \%$ in Sweden when the spray-free GM fruits were sold at a discount of $15 \%$ (Knight et al. 2007). The Federation of Swedish farmers (Lantbrukarnas Riksförbund, LRF) proposes that 


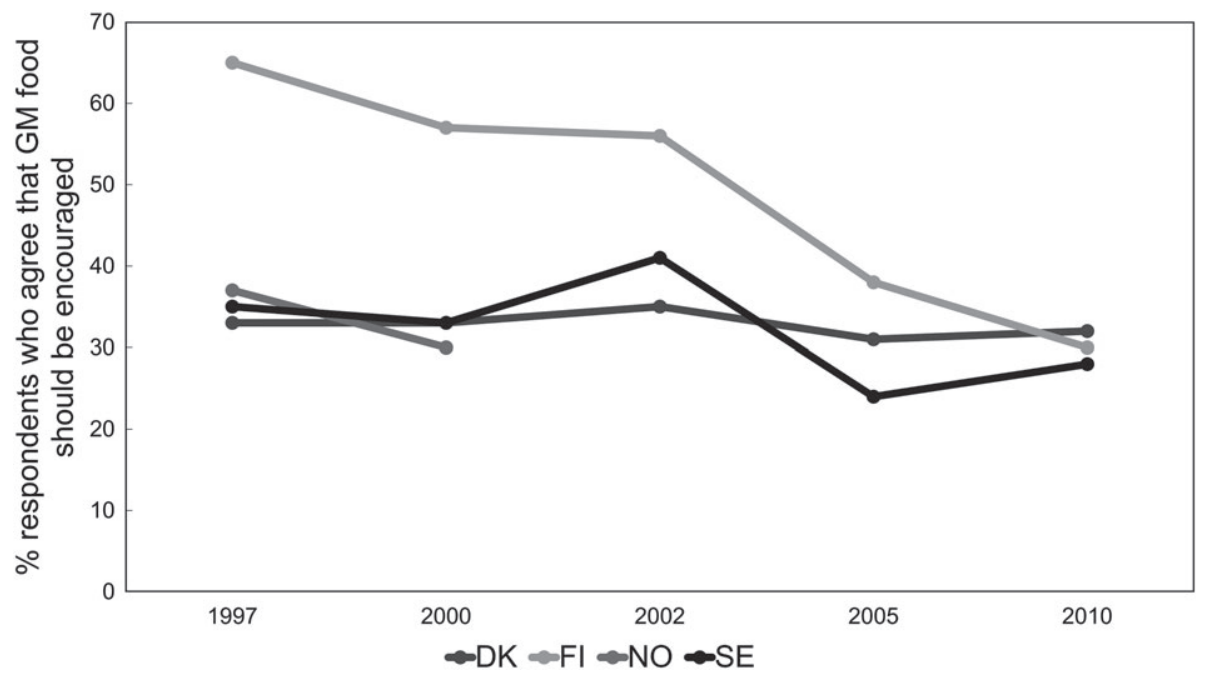

Fig. 5. Percentage of respondents who agree that GM food should be encouraged, for Denmark, Finland, Norway and Sweden. Data from Eurobarometers 1997, 2000, 2002, 2005, 2010.

the regulations for GMO in Sweden should be updated. GM soybean is not used in Sweden for fodder resulting in increased expenses for purchasing conventionally grown soybean. Almost all meat and milk products imported in Sweden are from cattle fed with GM fodder. LRF thus suggests that new traits in plants should be introduced for sustainable practices irrespective of the technique used to introduce the trait. The dairy industry in Sweden has for many years had a policy not to use GMO as animal feed. In 2014, this policy was removed, however, Sweden's largest milk producer, Arla, still maintains the policy and has decided to provide a compensation to the Swedish dairy farmers for using non-GM fodder (Arla 2017). An investigation was carried out on the views on biotechnology among the five actors in the Swedish food supply chain (Björnberg et al. 2015); the two organisations that are owned by the Swedish farmers, namely LRF and Lantmännen, and the three big food retailers ICA, Axfood and Coop. The authors studied how these five actors perceive the concept of agricultural sustainability and the role of biotechnology in creating more sustainable agricultural production systems. In their study, LRF was positive towards $\mathrm{GMO}$ in agriculture if it contributed positively both environmentally and economically without affecting the human and animal health negatively. According to the study, Lantmännen acknowledges the potential of biotechnology for sustainable agriculture; however, they adopt a precautionary principle and is also based on the demands and requirements of their customers as well as the overall opinion in their market(s). Among the three big retailers, ICA and Axfood do not have a cohesive policy towards GMO and considers it important to label the GM-based products appropriately, while Coop believes that GMO might have a negative impact both on the environment and the farmers. None of the three retailers sell any products containing GM ingredients (Björnberg et al. 2015).

It is challenging to compare the stakeholder and public attitudes to plant gene technologies among the four Scandinavian countries, as most studies have different scopes and setups. For comparative data on public opinions, the regular Eurobarometer gives useful long-term information. When looking at the data for the Scandinavian countries from the Eurobarometers from 1997, 2000, 2002, 2005 and 2010 (including Norway for 1996 and 1999), we see that the percentage of respondents who are in favour of GM food applications have been similar, at a rather low level of $25-40 \%$, for Denmark, Norway and Sweden over the period. Finland on the other hand had a much higher public support early in the period but has seen a steady decrease down to the level of the other countries (Fig. 5) (Eurobarometer 1997, 2000, 2002, 2005, 2010).

\section{Discussion and future perspectives}

The Scandinavian region, situated in the European high north, is not only unique concerning climate, temperature and daylight, but also regarding specific regulations of fertiliser and pesticide uses. Crops specifically adapted to these conditions have been developed for many decades through the ongoing efforts of public plant breeding programmes as well as small- and medium-size breeding companies concentrating their efforts especially for these conditions (Andersen et al. 2013, Nilsson et al. 2016). However, the current global 
trend of concentrating breeding companies into large multinational entities focusing on major crops and large markets potentially poses a challenge for the development of crops well adapted to the unique climate of the Scandinavian countries. It is therefore essential that plant breeding efforts specifically for this part of the world continue in order to meet the common goals within the Scandinavian countries of a sustainable agriculture with reduction of its environmental footprints, i.e. reduction of pesticides and an efficient use of fertiliser. An additional and highly relevant challenge in the coming years is that the global warming is expected to raise the average temperature with $1-1.5^{\circ} \mathrm{C}$ over the next 50 years. A prolonged growth season and change in the rainfall pattern in Scandinavia is expected to lead to increased stress and pressure from diseases and pests. These problems can only be solved through plant breeding to specific areas. However, breeding of crops is a long and competitive process, and plant gene technologies are considered key elements for future successful breeding.

The European continent is often depicted as being politically highly restrictive to the application of plant gene technology, including GMO. However, in reality there is large variation among the countries regarding the policies and political attitudes to plant gene technology. About 8-10 countries (of EU-28) can be described as highly restrictive whereas another $8-10$ actually have a rather permissive attitude to GM applications. Of the Scandinavian EU Member States, Denmark is the only one that has implemented the Directive (EU) 2015/412 and requested that the Danish territory should be excluded from authorization to cultivate the GM maize events MON810, 1507, Bt11 and GA21. It makes sense that the other Scandinavian countries have not delivered similar requests, as the GM events in question are not relevant to agriculture in the far north of Europe. It will be interesting though to follow the development in the other Scandinavian countries regarding the Directive (EU) 2015/412, if other GM events eventually reach the market. The regular voting behaviour in the EU gives general indications to the political attitudes to plant gene technology. A study from 2015 by EuropaBio (EuropaBio 2015) indicated that Denmark and Sweden tended to vote according to the scientific advice for GM applications in 2014, though perhaps not in every instant, and Finland is among the group of about 10 EU countries who always followed science in their votings in 2014. Mühlböck and Tosun (2015) analysed the voting behaviour for GM events in the EC over the period 2004-2014 and found that Sweden and Finland are among the most permissive countries with nearly $100 \%$ of the votes in favour of GM approval, whereas Denmark is found somewhere in the middle of the
EU-28 list with about $60 \%$ of votes in favour and about $40 \%$ of votes against GM event authorizations. Also, a study by Smart et al. (2015) of the EU Member States' voting behaviour on GM events in 2003-2015 confirms this general picture. According to this study, Finland was the only country that voted in favour of authorisation of GM crops for food and feed use every time (under Regulation 1829/2003) in the Standing Committee on the Food Chain and Animal Health (SCFCAH), and nearly every time in the Appeal Committee (AC), in the years 2003-2015. Sweden is not far behind with 54 (of 61) and 50 (of 57) of the votes in the SCFCAH and the AC, respectively, in favour of authorisation. Denmark has a slightly less favourable voting record though, with 38 respective 34 votes in favour in these committees (Fig. 6); however, in an EU-28 context this is still relatively complaisant to the EFSA evaluations. A notable exception to the trend of Sweden to follow the scientific advice provided by EFSA occurred in the latest votes on 27 January 2017 in the Regulatory Committee (under Directive 2001/18/EC) and 27 March 2017 (Appeal Committee) when Sweden voted against authorisation for cultivation of two maize events (Bt11 and 1507) that are insect-resistant and herbicide (gluphosinate ammonium)-tolerant (AGRA FACTS 2017; Greenpeace European Unit 2017). According to the Swedish Minister of the Environment, Karolina Skoog, this was because cultivation of these two maize events is considered to be in conflict with one of the Swedish Environmental Objectives (Swedish Environmental Protection Agency), namely $A$ non-toxic environment. It goes beyond the scope of this article to analyse in further detail all the reasons for this voting pattern among the Scandinavian countries; however, we do notice an overall tendency among the Scandinavian countries, in particular perhaps Finland and Sweden, to represent an innovation-friendly and scientifically motivated attitude towards plant gene technology (Fig. 6), when seen against a European background.

Also for stakeholder/public opinions about plant gene technology, there is large variation among European countries. Even though national surveys in, e.g. Norway (Bugge and Bartmann 2017) (Hess et al. 2013) indicate that many people are negative to plant gene technology, a closer look at the most recent Eurobarometer on Biotechnology, which is from 2010, shows that people from Denmark, Finland, Norway and Sweden tend to be slightly less negative to GM food in comparison to many other European countries, though the level of respondents being in favour of GM food is still rather low. The awareness of the technology is nevertheless often high across these four countries, with $87-96 \%$ of the respondents having heard about $\mathrm{GM}$ food. The attitudes towards GM food tend to be slightly more positive than the EU-27 


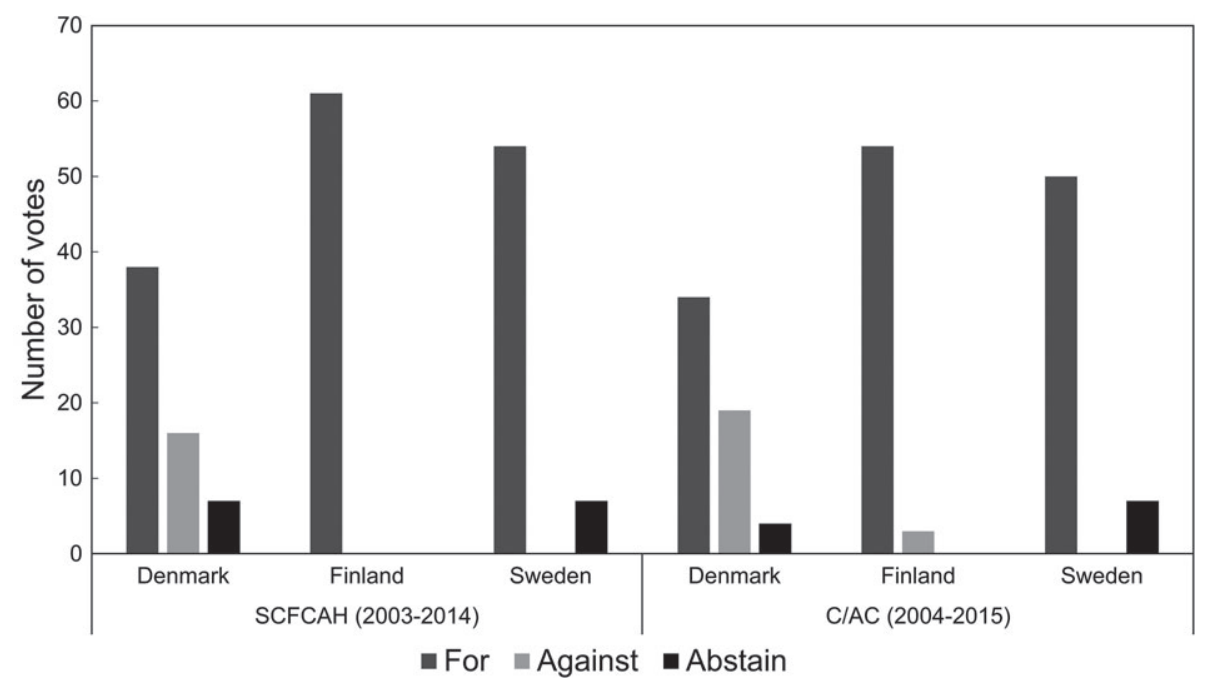

Fig. 6. Voting pattern of Denmark, Finland and Sweden on GMO authorizations at the Standing Committee on the Food Chain and Animal Health (SCFCAH) from December 2003 to December 2014 and at the Council/Appeal Committee from May 2004 to February 2015. Data adopted from Smart et al. (2015). F, for; A, against; O, abstain. SCFCAH, Standing Committee on the Food Chain and Animal Health; C/AC, Commission/Appeal Committee.

(as of 2010) average, here with Denmark at the higher range whereas Sweden would for a few of the questions have slightly more negative responses (European Commission 2010). Even though it is difficult to ascertain whether or not the national policies on plant gene technology in the Scandinavian countries reflect the public and/or other stakeholder opinions - or vice versa - at least there appears to be no apparent conflict between the two.

The Scandinavian region is unique in several aspects. At the same time the relatively small market sizes of the countries in this region may act as a limiting factor to private investments in regionally adapted breeding. Apart from the importance of substantial and long-term stable public investments, it is therefore also imperative to discuss the role and regulation of innovative solutions in Scandinavian plant research and breeding. All Scandinavian countries position themselves relatively well in the overall strategies to develop sustainable bioeconomies in Europe, and most of them have recently also adopted a national bioeconomy strategy. However, strategy is nothing without a clear implementation plan. It is important that all Scandinavian countries quickly get new bio-based entrepreneurship running to fully exploit the growth possibilities of a bioeconomy. Plant gene technology is definitely contributing to these growth prospects.

\section{Author contributions}

D. E. and A. C. took the initiative to the manuscript. All co-authors contributed equally with their respective country-specific information and to the discussion. D. E. was additionally responsible for the introduction and for assembling and formatting all text material.

Acknowledgements-This work was supported by the Swedish Foundation for Strategic Environmental Research (Mistra) through the Mistra Biotech research programme. We would also like to thank Marie Nyman at the Swedish Gene Technology Advisory Board, Heléne Ström at the Swedish Board of Agriculture, Hannele Leiwo and Kirsi Törmäkangas at the Finnish Board of Gene Technology (GTLK), Matti Sarvas, Aslaug Ragnhild Hagen at the Norwegian Food Safety Authority, and Jakob Koldingsnes at The Norwegian Environment Agency for valuable comments and material.

\section{References}

Advisory Board on Biotechnology. Available at http://www .btnk.fi/en/index.html (accessed 31 May 2017)

Andersen SB, Thomsen TH, Jensen CS, Rasmussen M, Gylling M, Haastrup M, Bertelsen I, Jahoor A, Nielsen BS (2013) "Better crops for future agriculture" - An analysis of the potential for breeding better plant varieties. Available at http://ffst.dk/fileadmin/user_ upload/NaturErhverv/Filer/Landbrug/Genetiske_ ressourcer/Planter/Publikationer/English_summaryof_ the_report.pdf (accessed 31 May 2017)

Andersson M, Turesson H, Nicolia A, Falt AS, Samuelsson M, Hofvander P (2017) Efficient targeted multiallelic mutagenesis in tetraploid potato (Solanum tuberosum) 
by transient CRISPR-Cas9 expression in protoplasts.

Plant Cell Rep 36: 117-128

Arla Frågor och svar om GMO. Available at https://www .arla.se/bondeagda-arla/kontakta-oss/vanliga-fragorsvar/fragor-och-svar-om-gmo-och-foder/ (accessed 31 May 2017)

Aronen TS, Nikkanen TO, Haggman HM (1998) Compatibility of different pollination techniques with microprojectile bombardment of Norway spruce and scots pine pollen. Can J For Res 28: 79-86

Aronen TS, Nikkanen TO, Haggman HM (2003) The production of transgenic scots pine (Pinus Sylvestris L.) via the application of transformed pollen in controlled crossings. Transgenic Res 12: 375-378

Barton KA, Binns AN, Matzke AJM, Chilton MD (1983) Regeneration of intact tobacco plants containing full length copies of genetically engineered T-DNA, and transmission of T-DNA to R1-progeny. Cell 32: 1033-1043

Björnberg K, Jonas E, Marstorp H, Tidåker P (2015) The role of biotechnology in sustainable agriculture: views and perceptions among key actors in the Swedish food supply chain. Sustainability 7: 7512-7529

Board for Gene Technology (2017) Available at http:// geenitekniikanlautakunta.fi/en/deliberate-release/ authorised-field-trials (accessed 31 May 2017)

Bosselmann AS, Jensen MV, Gylling M (2015) Protein forbrug i danske konventionelle og økologiske husdyrproduktioner IFRO Udredning; Nr 2015/02

Bugge BH, Bartmann A (2017) Fremtidens matproduksjon. Forbrukernes syn på genmodifisert mat: GMO-mat eller ikke? Oppdragsrapport nr. 2.

Forbruksforskningsinstituttet SIFO, Høgskolen i Oslo og Akershus, Oslo

Casacuberta JM, Nogué F, Du Jardin P (2017) GMO risk assessment in the EU: interplay between science, policy and politics. In: San-Epifanio LE (ed) Towards a new regulatory framework for GM crops in the European Union. Scientific, ethical, social and legal issues and the challenges ahead. Wageningen Academic Publisher, Wageningen, pp 200

Cohen J (2016) Did a Swedish researcher eat the first CRISPR meal ever served? Science. Available at http:// www.sciencemag.org/news/2016/09/did-swedishresearcher-eat-first-crispr-meal-ever-served (accessed 31 May 2017)

Det Etiske Råd (2016) Den Etiske Forbruger - Redegørelse. Available at http://www.etiskraad.dk/ /media/EtiskRaad/Etiske-Temaer/Natur-klima-og-foedevarer/ Publikationer/2016-Den-etiske-forbruger.pdf (accessed 31 May 2017)

EASAC (2017) Genome editing: scientific opportunities, public interests and policy options in the European Union. European Academies Science Advisory Council, Policy Report 31
Elomaa P, Honkanen J, Puska R, Seppanen P, Helariutta Y Mehto M, Kotilainen M, Nevalainen L, Teeri TH (1993)

Agrobacterium-mediated transfer of antisense chalcone synthase cDNA to gerbera-hybrida inhibits flower pigmentation. Bio-Technology 11: 508-511

Eriksson D, Carlson-Nilsson U, Ortiz R, Andreasson E (2016) Overview and breeding strategies of table potato production in Sweden and the Fennoscandian region. Potato Res 59: 279-294

EuropaBio (2015) EU Member States and GMOs: What they say and what they do. Available at http://www .growingvoices.eu/articles/526/INFOGRAPHIC-EUMember-States-and-GMOs.pdf (accessed 31 May 2017)

Eurobarometer (1997) The Europeans and modern biotechnology. Eurobarometer 46.1

Eurobarometer (2000) The Europeans and biotechnology. Eurobarometer 52.1

Eurobarometer (2002) Europeans and biotechnology in 2002. Eurobarometer 58.0

Eurobarometer (2005) Europeans and biotechnology in 2005: patterns and trends. Eurobarometer 64.3.

Eurobarometer (2010) Biotechnology. Eurobarometer 73.1

European Commission (2012a) Deliberate Release and Placing on the EU Market of GMOs - GMO Register. Available at http://gmoinfo.jrc.ec.europa.eu/gmp_ browse.aspx (accessed 31 May 2017)

European Commission (2012b) Deliberate Release and Placing on the EU Market of GMOs - GMO Register Denmark. Available at http://gmoinfo.jrc.ec.europa.eu/ overview/DK.asp (accessed 31 May 2017)

European Commission (2012c) Deliberate Release and Placing on the EU Market of GMOs - GMO Register Norway. Available at http://gmoinfo.jrc.ec.europa.eu/ overview/NO.asp\#top (accessed 31 May 2017)

Finnish Food Safety Authority (2017) Genetically Modified Food. Available at https://www.evira.fi/en/foodstuff/ manufacture-and-sales/common-requirements-forcomposition/genetically-modified-food-gmo/ (accessed 31 May 2017)

Fladung M (2016) Cibus' herbicide-resistant canola in European limbo. Nat Biotechnol 34: 473-474

Hartung F, Schiemann J (2014) Precise plant breeding using new genome editing techniques: opportunities, safety and regulation in the EU. Plant J 78: 742-752

Helariutta Y, Elomaa P, Kotilainen M, Seppanen P, Teeri TH (1993) Cloning of cDNA coding for Dihydroflavonol-4-reductase (DFR) and characterization of DFR expression in the corollas of gerbera-hybrida Var Regina (Compositae). Plant Mol Biol 22: 183-193

Herrera-Estrella L, Block MD, Messens E, Hernalsteens JP, Montagu MV, Schell J (1983) Chimeric genes as dominant selectable markers in plant cells. EMBO J 2: 987-995

Hess S, Lagerkvist CJ, Redekop W, Pakseresht A (2013) Consumers' evaluation of biotechnology in food 
products: new evidence from a meta-survey. Agricultural \& Applied Economics Association's 2013 AAEA \& CAES Joint Annual Meeting, Washington, DC, 4-6 August 2013

HLG-SAM (2017) New Techniques in Agricultural Biotechnology. Explanatory Note 02. European Commission High Level Group of the Scientific Advisory Mechanism, Brussels

Hollo EJ (2016) Genetic Technology and Food Safety: Country Report - Finland. 14, pp 153-169

Holme IB, Dionisio G, Brinch-Pedersen H, Wendt T, Madsen CK, Vincze E, Holm PB (2012) Cisgenic barley with improved phytase activity. Plant Biotechnol J 10: 237-247

Hvoslef-Eide AK (1995) The Gene Technology Act - how will the Environmental Authorities in Norway Handle the Ethical Issues? Studies in Research Ethics. Centre for Research Ethics, Gothenburg

Hvoslef-Eide AK, Fjeld T, Einset JW (1995) Breeding Christmas Begonia (Begonia X Cheimantha Everett) for increased keeping quality by traditional and biotechnological methods. Acta Hortic 405: 197-204

Häggman HM, Aronen TS, Nikkanen TO (1997) Gene transfer by particle bombardment to Norway spruce and scots pine pollen. Can J For Res 27: 928-935

ISAAA (2016) Global Status of Commercialized Biotech/GM Crops ISAAA Brief No 52

Kaljonen M, Rikkonen P (2004) Divergent images of multifunctional agriculture: a comparative study of the future images between farmers and agri-food experts in Finland. Int J Agr Sustain 2: 190-204

Klima- og miljødepartementet (2000) Forskrift om forbud mot omsetning i Norge av bestemte genmodifiserte produkter. Available at https://lovdata.no/dokument/SF/ forskrift/2000-12-15-1268 (accessed 10 October 2017).

Klima- og miljødepartementet (2015a) Endringer i antall direktivgodkjente GMO-er som kan omsettes i Norge. Available at https://www.regjeringen.no/no/aktuelt/ endringer-i-antall-direktivgodkjente-gmo-er-som-kanomsettes-i-norge/id2412749/ (accessed 31 May 2017)

Klima- og miljødepartementet (2015b) Lov om framstilling og bruk av genmodifiserte organismer m.m. (genteknologiloven). Available at https://lovdata.no/ dokument/NL/lov/1993-04-02-38 (accessed 31 May 2017)

Knight JG, Mather DW, Holdsworth DK, Ermen DF (2007) Acceptance of GM food--an experiment in six countries. Nat Biotechnol 25: 507-508

Lassen J, Jensen KK, Sandøe P (2009) Etik og nytteværdi: holdningsanalyser. GMO - hvad kan vi bruge det til? Fødevareministeriets vidensyntese om brug af genmodificerede afgrøder i landbrugs-og fødevareproduktion, pp 159-176

Library of Congress (2015a) Restrictions on Genetically Modified Organisms: European Union. Available at https://www.loc.gov/law/help/restrictions-on-gmos/eu .php\#_ftn7 (accessed 31 May 2017)

Library of Congress (2015b) Restrictions on Genetically Modified Organisms: Sweden. Available at https://www .loc.gov/law/help/restrictions-on-gmos/sweden.php\#_ ftn1 (accessed 31 May 2017)

Logan T (2017) Gene editing is different to genetic modification, so should its regulation be relaxed? Australia Broadcasting Corporation News. Available at http://www.abc.net.au/news/rural/2017-03-24/geneediting-is-different-to-genetic-modification/8383278 (accessed 3 November 2017)

Lowder L, Malzahn A, Qi Y (2016) Rapid evolution of manigw CRISPR Systems for Plant Genome Editing. Front Plant Sci 7: 1683

Lusk JL, Jamal M, Kurlander L, Roucan M, Taulman L (2005) A meta-analysis of genetically modified food valuation studies. J Agric Resourc Econ 30: 28-44

Lusser M, Davies HV (2013) Comparative regulatory approaches for groups of new plant breeding techniques. N Biotechnol 30: 437-446

Maa- ja metsätalousministeriö (2017) Available at http:// mmm.fi/muuntogeeniset-ja-uuselintarvikkeet (accessed 31 May 2017)

MacManus R (2017) NZ could miss out on gene-editing revolution. Newsroom. Available at https://www .newsroom.co.nz/2017/04/02/17700/the-gene (accessed 3 November 2017)

Madsen KH, Kudsk P, Jensen PE, Haldrup C, Jensen LS (2001) Danish experiences with genetically modified herbicide resistant crops. In: DJF-Rapport, Vol. 41, pp 145-155

Maki-Valkama T, Pehu T, Santala A, Valkonen JPT, Koivu K, Lehto K, Pehu E (2000) High level of resistance to potato virus $\mathrm{Y}$ by expressing $\mathrm{P} 1$ sequence in antisense orientation in transgenic potato. Mol Breed 6: 95-104

Maki-Valkama T, Valkonen JPT, Lehtinen A, Pehu E (2001) Protection against potato virus $Y(P V Y)$ in the field in potatoes transformed with the PVYP1 gene. Am J Potato Res 78: 209-214

Mattilsynet (2013) Forlengelse av dispensasjon fra godkjenningskrav - GM-fiskefôr. Available at https:// www.mattilsynet.no/planter_og_dyrking/ genmodifisering/forlengelse_av_dispensasjon_fra_ godkjenningskrav__gmfiskefor.10954 (accessed 31 May 2017)

Mattilsynet (2014) Bakgrunn for avslag om å bruke genmodifisert fiskefôr. Available at https://www .mattilsynet.no/planter_og_dyrking/genmodifisering/ bakgrunn_for_avslag_om_aa_bruke_genmodifisert_ fiskefor.16613 (accessed 31 May 2017)

Mielby H, Sandøe P, Lassen J (2013) Multiple aspects of unnaturalness: are cisgenic crops perceived as being more natural and more acceptable than transgenic crops? Agric Human Values 30: 471-480 
Ministeriet for Fødevarer Landbrug og Fiskeri (2014)

Fødevareministeriets positionspapir (udvidet version):

"Fremtidens Plantesorter". Available at http://lfst.dk/

fileadmin/user_upload/NaturErhverv/Filer/Landbrug/

Genetiske_ressourcer/Planter/Publikationer/bilag_2_

positionspapir_final.pdf (accessed 31 May 2017)

Mühlböck M, Tosun J (2015) Deciding over controversial issues: Voting behavior in the Council and the European Parliament on genetically modified organisms. GMCC Amsterdam, 17-20 November 2015

Nicolia A, Proux-Wera E, Ahman I, Onkokesung N, Andersson M, Andreasson E, Zhu LH (2015) Targeted gene mutation in tetraploid potato through transient TALEN expression in protoplasts. J Biotechnol 204: $17-24$

Nilsson A, Rv B, Johanesson T, Nybom H, Bendevis MA, Bengtsson T, Rognli OA (2016) Promoting Nordic Plant Breeding: PPP Public Private Partnership for Pre-breeding, Nordisk Ministerråd, ANP, 2016:730, Copenhagen

Official Journal of the European Communities (2001) Directive 2001/18/EC of the European Parliament and of the Council of 12 March 2001 on the deliberate release into the environment of genetically modified organisms and repealing Council Directive 90/220/EEC

Official Journal of the European Communities (2003) Regulation (EC) No 1829/2003 of the European Parliament and of the Council of 22 September 2003 on genetically modified food and feed

Official Journal of the European Union (2003) Regulation (EC) No 1830/2003 of the European Parliament and of the Council of 22 September 2003 concerning the traceability and labelling of genetically modified organisms and the traceability of food and feed products produced form genetically modified organisms and amending Directive 2001/18/EC

Pennisi E (2012) The Tale of the TALEs. Science 338: 1408-1411

Petolino JF (2015) Genome editing in plants via designed zinc finger nucleases. In Vitro Cell Dev Biol Plant 51: $1-8$

Quetier F (2016) The CRISPR-Cas9 technology: closer to the ultimate toolkit for targeted genome editing. Plant Sci 242: 65-76

Ritala A, Aspegren K, Kurten U, Salmenkalliomarttila M, Mannonen L, Hannus R, Kauppinen V, Teeri TH, Enari TM (1994) Fertile transgenic barley by particle bombardment of immature embryos. Plant Mol Biol 24: $317-325$

Ritala A, Nuutila AM, Aikasalo R, Kauppinen V, Tammisola J (2002) Measuring gene flow in the cultivation of transgenic barley. Crop Sci 42:

278-285

Rognli OA, Potter R (1991) Konsekvensutredning i forbindelse med utsetting av transgene poteter i Norge. DN-kontrakt nr. Btek 5/1991, Institutt for Bioteknologifag, NLH, $44 \mathrm{~s}$.

Sauer NJ, Mozoruk J, Miller RB, Warburg ZJ, Walker KA, Beetham PR, Schopke CR, Gocal GF (2016) Oligonucleotide-directed mutagenesis for precision gene editing. Plant Biotechnol J 14: 496-502

Smart RD, Blum M, Wesseler J (2015) EU member States' voting for authorizing genetically engineered crops: a regulatory gridlock. Ger J Agr Econ 64: 244-262

Smyth SJ (2017) Canadian regulatory perspectives on genome engineered crops. GM Crops \& Food 8:1: 35-43

Sprink T, Eriksson D, Schiemann J, Hartung F (2016) Regulatory hurdles for genome editing: process- vs. product-based approaches in different regulatory contexts. Plant Cell Rep 35: 1493-1506

Swedish Board of Agriculture Fältförsök (2017) Available at http://www.jordbruksverket.se/amnesomraden/odling/ genteknikgmo/faltforsok.4 .300b18bd13d103e79ef80002497.html (accessed 31 May 2017)

Swedish Board of Agriculture (2015) CRISPR/Cas9 mutated Arabidopsis. Available at https://www.upsc.se/ documents/Information_on_interpretation_on_CRISPR_ Cas9_mutated_plants_Final.pdf (accessed 31 May 2017)

Swedish Environmental Protection Agency Environmental Objectives. Available at http://www.miljomal.se/ Environmental-Objectives-Portal/\# (accessed 31 May 2017)

Tolstrup K, Andersen SB, Boelt B, Buus M, Gylling M, Bach Holm P, Kjellsson G, Pedersen S, Østergaard H, Mikkelsen SA (2003) Report from the Danish Working Group on the co-Existence of Genetically Modified Crops with Conventional and Organic Crops, Vol. 94. Ministry of Food, Agriculture and Fisheries, København

Tolstrup K, Andersen SB, Boelt B, Buus M, Gylling M, Bach Holm P, Kjellsson G, Pedersen S, Østergaard H, Mikkelsen SA (2007) Supplerende rapport fra Udredningsgruppen vedrørende Sameksistens mellem genetisk modificerede, konventionelle og økologiske afgrøder: Opdatering af Udredningen fra 2003. Aarhus

Whelan AI, Lema MA (2015) Regulatory framework for gene editing and other new breeding techniques (NBTs) in Argentina. GM Crops Food 6: 253-265

Wolt JD, Yang B, Wang K, Spalding MH (2016) Regulatory aspects of genome-edited crops. In Vitro Cell Dev Biol Plant 52: 349-353

Edited by V. Hurry 